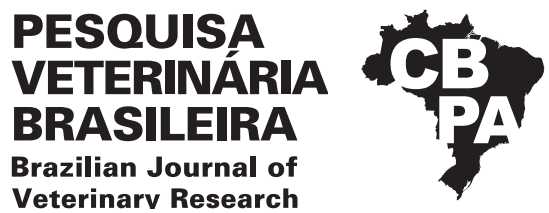

Pesq. Vet. Bras. 41:e06744, 2021

DOI: $10.1590 / 1678-5150-P V B-6744$

Original Article

Livestock Diseases

ISSN 0100-736X (Print)

ISSN 1678-5150 (Online)

\title{
Digestive disorders associated with the consumption of palm fiber (Elaeis guineensis) in feedlot cattle ${ }^{1}$
}

\author{
Natalia Maxine F.P. Sarmento², Márcio Alan O. Moura², Rosekelly J. Cardoso², \\ Adrielli Heloise A. Lima², Pedro S. Bezerra Junior², Marcos D. Duarte², \\ Valíria D. Cerqueira ${ }^{2}$ and Gabriela Riet-Correa ${ }^{2 *}$ (D)
}

\begin{abstract}
Sarmento N.M.F.P., Moura M.A.O., Cardoso R.J., Lima A.H.A., Bezerra Junior P.S., Duarte M.D., Cerqueira V.D. \& Riet-Correa G. 2021. Digestive disorders associated with the consumption of palm fiber (Elaeis guineensis) in feedlot cattle. Pesquisa Veterinária Brasileira 41:e06744, 2021. Laboratório de Patologia Animal, Instituto de Medicina Veterinária, Universidade Federal do Pará, BR-316 Km 61, Bairro Saudade, Castanhal, PA 68746-360, Brazil. E-mail: griet@ufpa.br

Digestive disorders in cattle are associated with the breeding system and feed provided to the animals. Abomasal compaction is primarily related to the ingestion of forage with elevated levels of lignin, low quality, and difficult digestibility. In addition, the excess of fibrous food in the diet can lead to phytobezoars that may be responsible for intestinal obstruction disorders. This study aimed to describe pathological and clinical aspects of an outbreak of digestive disorders associated with the consumption of palm fiber (Elaeis guineensis). The outbreak struck a herd of 499 animals raised in a feedlot system after a change in diet that included an increase in the amount of palm fiber. Forty (8.01\%) animals showed clinical signs such as fattening and regurgitation during rumination, and $21(4.2 \%)$ animals died later. The cattle affected presented with apathy, emaciation, dehydration, distended abdomen, incomplete or absent ruminal movements, and congestive mucosa. Three animals were submitted to necropsy, and distended rumen and reticulum has a large amount of brownish liquid, long and tangled vegetable fibers with sand and stones. In two animals, the omasum had many rounded structures measuring approximately $5 \mathrm{~cm}$ in diameter, made of vegetable fiber (phytobezoars). Abomasum of animals had similar material to the rumen, and one animal had compressed content. In two animals, dilatation was observed in the small intestine, and in the opening, the total obstruction of the lumen by phytobezoar was observed. During the follow-up of the slaughter of 76 cattle, 15 $(19.7 \%)$ had phytobezoars of different sizes in the omasum and abomasum. The increased amount of oil palm fiber in animal feeding favored the occurrence of compression abomasum and intestinal obstruction phytobezoa, causing significant economic losses.
\end{abstract}

INDEX TERMS: Digestive disorder, palm fiber, Elaeis guineensis, feedlot, cattle, compaction, phytobezoar, digestive system.

RESUMO.- [Distúrbios digestivos associados ao consumo de fibra de dendê (Elaeis guineensis) em bovinos criados em regime de confinamento.] Alguns distúrbios digestivos em bovinos podem estar associados ao sistema de criação e alimentação dos animais. Entre estes estão à compactação de abomaso e a obstrução intestinal por fitobezoários, ambas relacionadas principalmente com a ingestão de alimentos

\footnotetext{
${ }^{1}$ Received on July 6, 2020.

Accepted for publication on September 7, 2020.

${ }^{2}$ Laboratório de Patologia Animal, Instituto de Medicina Veterinária, Universidade Federal do Pará (UFPA), BR-316 s/n, Castanhal, PA 68740-000, Brazil. *Corresponding author: griet@ufpa.br
}

com altos níveis de lignina e, consequentemente, de difícil digestibilidade. Neste trabalho são descritos os aspectos clínicos e patológicos de um surto de distúrbios digestivos em bovinos associados ao consumo de fibra de dendê (Elaeis guineensis). 0 surto acometeu um rebanho de 499 bovinos, criados em sistema de confinamento, após uma mudança na dieta que incluiu o aumento na quantidade de fibra de dendê. Após a mudança 40 animais $(8,01 \%)$ apresentaram diarreia, distensão abdominal e regurgitação durante a ruminação e 21 animais $(4,2 \%)$ morreram. Os bovinos examinados clinicamente apresentavam sinais de apatia, emagrecimento, desidratação, abdômen distendido, movimentos ruminais incompletos e 
ausentes, além de mucosas congestas. Três animais foram submetidos à necropsia e observou-se rúmen e reticulo distendidos e com grande quantidade de líquido acastanhado, fibras vegetais longas e emaranhadas e presença de areia e pedras. Em dois animais o omaso continha grande número de estruturas arredondadas medindo aproximadamente $5 \mathrm{~cm}$ de diâmetro, constituídas de fibras vegetais (fitobezoários). No abomaso dos animais havia material semelhante ao do rúmen, sendo que um animal apresentou conteúdo compactado e um deles também tinha fitobezoários. Em dois animais foram observadas dilatação e obstrução total do lúmen do intestino delgado por fitobezoários. Durante o acompanhamento do abate de 76 bovinos, $15(19,7 \%)$ apresentavam fitobezoários de diferentes tamanhos no abomaso e omaso. 0 aumento da quantidade de fibra de dendê na alimentação dos animais favoreceu a ocorrência de casos de compactação de abomaso e obstrução intestinal por fitobezoários, ocasionando perdas econômicas significativas.

TERMOS DE INDEXAÇÃO: Distúrbio digestivo, fibra de dendê, Elaeis guineensis, bovinos, confinamento Elaeis guineensis, compactação, fitobezoário, sistema digestivo.

\section{INTRODUCTION}

Abomasum compaction is characterized as the accumulation of solid food in the abomasum with difficulty in emptying. It can be classified as primary, caused by the ingestion of low-quality foods rich in lignin, and by water restriction, or secondary, related to cases of vagal indigestion. (Moscardini \& Borges 2007). Phytobezoars, intussusception, and volvulus often cause intestinal obstruction in cattle, the latter being rarely identified. The phytobezoar's solid structures are formed from plant residues rich in indigestible fibers within the gastrointestinal system (Bath \& Bergh 1979). The obstruction by phytobezoars is commonly related to the ingestion of forages with high levels of lignin and can be located in segments of the duodenum and jejunum (Afonso \& Costa 2007).

In Brazil, with the growth of biodiesel production, byproducts appear as good options for feeding ruminants, mainly in confinement systems where alternative foods are increasingly used to reduce costs (Cunha et al. 2012).

The leading world palm oil producers are Malaysia and Indonesia, with an estimated export of one million tons (USDA 2019). Brazil is the ninth largest world producer, with 14 thousand tons of palm oil from 2019 to 2020 (USDA 2020). In 2018, Pará state produced 1,533,735 tons of palm oil bunches, classified as the primary palm oil-producing state in Brazil (IBGE 2019). Palm oil pie, a by-product of biodiesel production, has been used to feed cattle in northern Brazil due to its wide availability and low cost (Maciel et al. 2012). On the other hand, palm fiber, which corresponds to approximately $12 \%$ of the bunch of fresh fruit, has a high-fat content, reduced protein content and a lower digestibility coefficient, demonstrating the restricted possibility of utilization in the feeding of animals (Rodrigues Filho et al. 2001, Furlan Júnior 2006).

This study aimed to describe the clinical and pathological aspects of an outbreak of digestive disorders associated with the consumption of palm fiber (Elaeis guineensis) in cattle reared under confinement.

\section{MATERIALS AND METHODS}

Epidemiological and clinical data were obtained through two visits to the property. On the first visit, the herd was inspected, clinical examination of two affected animals and blood was collected from nine animals for hematological analysis. Subsequently, one animal was referred to the "Laboratório de Patologia Animal" at "Universidade Federal do Pará" (UFPA) for necropsy. Two more cattle were necropsied during the second visit, one who died spontaneously and one euthanized in extremis. During necropsies, fragments of all organs of the abdominal and thoracic cavity and central nervous system were collected, fixed in $10 \%$ buffered formalin, routinely processed for histological analysis, and stained with hematoxylin and eosin (HE).

Seventy six cattle from the affected batch were slaughter, and the abomasum and pre-stomachs were analyzed during the viscera inspection line.

\section{RESULTS}

The outbreak occurred in a herd composed of 499 adult bovines kept in feedlot regime. During 20 days, the animals received a diet (Diet 1 ) composed mainly of corn silage, corn, palm fiber, and palm sludge (Table 1). During this period, each animal ingested approximately $2.4 \mathrm{~kg}(19.4 \%)$ of palm fiber daily. After this period, a new diet (Diet 2) was offered, composed mainly of sorghum/corn and palm fiber, and the daily intake of palm fiber per animal increased from $2.4 \mathrm{~kg}$ (Diet 1) to $4.17 \mathrm{~kg}$ (Diet 2) (Table 1). After the change in diet, the animals began to show diarrhea, bloating, and regurgitation during rumination.

Part of the ingredients used in the animals' diets, such as corn and sorghum grains, beans in grains, cotton cake, nucleus, residues from the biscuit and macaroni industry, were stored in a shed. Other ingredients, such as palm fiber, palm oil sludge, and açai kernel, were stored on the ground in the open. During the feed preparation, a mechanical shovel-type machine was used to take the ingredients to the mixer. When the ingredients stored on the soil were removed, earth and stones were taken into the mixer and consequently supplied to the animals.

The main clinical signs observed were apathy, weight loss, dehydration, distended abdomen, and liquid noise when the animals were moved. The keepers reported that the rumen of some animals was punctured with trochanter releasing large amounts of liquid. In addition, there was a reduction in food consumption and the number of feces of the animals. The clinical evolution ranged from 3 hours to 4 days. During the physical examination, congested mucous membranes, signs of dehydration such as retraction of the eyeball, and reduction in skin turgor were observed. Ruminal movements were incomplete or absent, with a metallic sound at auscultation and ballooning. Forty $(40,8.01 \%)$ animals got sick, and 21 (4.2\%) died.

In the hematological analysis, leukocytosis was observed in six animals, with increased fibrinogen and total plasma proteins. At necropsy of Bovine 1, 2, and 3, congested ocular and oral mucosae, marked eyeball retraction, and abdominal dilation of organs such as rumen, abomasum, and duodenum was observed. There was a large amount of brownish liquid and long, tangled vegetable fibers (similar to the palm fiber used in food) (Fig.1A,B). There was also a large amount of 
Table 1. Average daily intake of each component of the ration of Diets 1,2 and 3 provided to the cattle

\begin{tabular}{|c|c|c|c|}
\hline Food & $\begin{array}{c}\text { Diet } 1(\mathrm{~kg} / \text { animal }) \\
7 / 26 \text { to } 8 / 14 \\
\end{array}$ & $\begin{array}{c}\text { Diet } 2(\mathrm{~kg} / \text { animal }) \\
8 / 15 \text { to } 9 / 1 \\
\end{array}$ & $\begin{array}{c}\text { Diet } 3(\mathrm{~kg} / \text { animal }) \\
9 / 2 \text { to } 9 / 17 \\
\end{array}$ \\
\hline Sorghum/corn & $2.3(18.6 \%)$ & $6.22(46.4 \%)$ & $4.33(26.2 \%)$ \\
\hline Palm oil/cotton cake & 0.3 & 0.55 & 0.9 \\
\hline Palm fiber & $2.4(19.4 \%)$ & $4.17(31.1 \%)$ & $1.9(11.5 \%)$ \\
\hline Oil palm & 3.33 & 1.4 & 2.6 \\
\hline Bean & 0.066 & 0.15 & 0.016 \\
\hline Corn silage & 3.2 & 0 & 0.7 \\
\hline Açai lump & 0.25 & 0.45 & 0.4 \\
\hline Cracker & 0.27 & 0.08 & 0.4 \\
\hline Kernel & 0.22 & 0.35 & 0.36 \\
\hline Noodle & 0 & 0.025 & 0.015 \\
\hline Barley & 0 & 0 & 2.4 \\
\hline Grass & 0 & 0 & 0.7 \\
\hline Cassava peel & 0 & 0 & 1.81 \\
\hline TOTAL & 12.34 & 13.40 & 16.53 \\
\hline
\end{tabular}
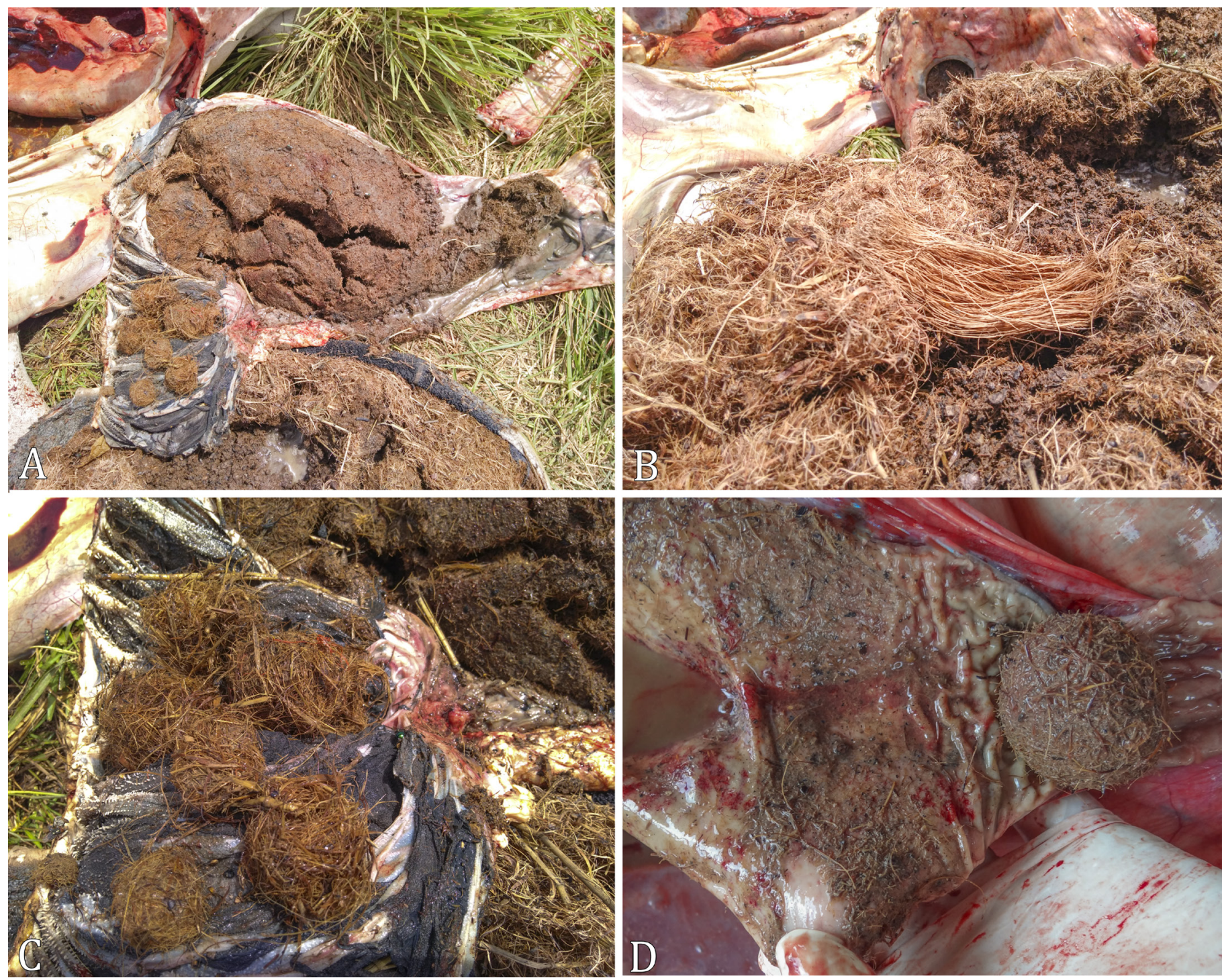

Fig.1. Digestive disorders associated with the consumption of oil palm fiber (Elaeis guineensis) in feedlot cattle. (A) Note the abomasum with compacted content consisting of vegetable fibers; rumen with compacted content, composed mainly of long vegetable fibers; and presence of phytobezoars in the omasum. (B) Rumen. Compressed content composed of a tangle of vegetable fibers. (C) Omasum containing phytobezoars. (D) Duodenum. Presence of a phytobezoar in the lumen and dilatation of the portion anterior to the obstruction. 
earth and stones from 1 to $2 \mathrm{~cm}$ in diameter. In the rumen of Bovine 1, the stones were separated and weighed, totaling $2.3 \mathrm{~kg}$. There was also a smaller amount of açai lumps in the rumen content. In the omasum of Bovine 1 and 2, there were a large number of rounded structures measuring approximately $5 \mathrm{~cm}$ in diameter, consisting of vegetable fibers (similar to palm fibers) (Fig.1A,C), of variable consistency (phytobezoars), some easy and others difficult to undo. In the abomasum of the animals, there was material similar to that of the rumen, and Bovine 2 had a compacted content, with a tangle of vegetable fibers occluding the pyloric region (Fig.1A). In Bovine 3, the rumen, reticulum, and abomasum contained a large amount of brownish liquid, earth, and stones from 1 to $2 \mathrm{~cm}$ in diameter, in addition to a smaller amount of açai seeds and long vegetable fibers (palm fibers). Bovine 1 had an enlarged duodenum, and about $40 \mathrm{~cm}$ from the pylorus, there was an area with hyperemia and hemorrhage in the serosa. At the opening, total obstruction of the lumen was observed by a phytobezoar. In addition, there was ulceration of the underlying mucosa and accumulation of brownish fluid similar to the portions before the obstruction (Fig.1D). In the initial portion of jejunum of Bovine 3 there was a lesion similar to that seen in the duodenum of Bovine 1, with total lumen obstruction by a phytobezoar.

We found no significant changes in the histopathology of Bovine 1, 2, and 3.

Diet 2 was offered for 18 days, being modified again due to digestive problems. In the new diet (Diet 3), there was a considerable reduction in the amount of palm fiber (Table 1); animal grass, barley (malt bagasse), and cassava peel were included in the animal feeding. After this new modification, new clinical cases of the disease or deaths were no longer reported.

Forty-seven (47) days after Diet 3, 76 cattle were sent to the slaughterhouse for slaughter. In the inspection conducted during slaughter we observed phytobezoa with different sizes; the larger had $12 \mathrm{~cm}$ and the smaller $5 \mathrm{~cm}$, located in the omasum and/or abomasum (Fig.1D) of 15 animals. We also observed that some animals had sand and stones, mainly in the abomasum.

\section{DISCUSSION}

Epidemiological data and clinicopathological findings carried out the diagnosis of abomasum compaction and intestinal obstruction by phytobezoars composed of palm fibers. The digestive changes observed in the present report are similar to those described in cattle ingesting other foods such as plants of the genus Stipagrostis, elephant grass weeding (Penisetum purpureum), sunflower silage, and Agave sisalana stem (Bath \& Bergh 1979, Ashcroft 1983, Borges et al. 2007, Câmara et al. 2009, Mesquita et al. 2012, Nascimento et al. 2016).

The outbreak morbidity was $8.0 \%$, and mortality was $4.2 \%$. However, during the slaughter of 76 cattle from the affected batch, phytobezoars were observed in the omasum and/or abomasum of 15 animals (19.7\%). This number indicates that a more significant number of animals in the batch may have been affected subclinically.

Primary abomasum compaction has already been described in cattle receiving banana stems (Musa sp.) (Helayel et al. 2012), sunflower silage (Mesquita et al. 2012), Agave sisalana stem (Nascimento et al. 2016), and weeds of elephant grass (Pennisetum purpureum) in an advanced state of maturity
(Borges et al. 2007, Câmara et al. 2009). In the present study, compaction was associated with the use of palm fiber in the diet.

In cattle, cases of abomasal compaction due to the ingestion of sand and stones are rare and can be related to metabolic disorders, depraved appetite, and errors in feeding management (Cebra et al. 1996, Melendez et al. 2007, Erickson \& Hendrick 2011). Ingestion of sand can also result in the compaction of other organs such as the omasum and large intestine and cause atony of the abomasum and chronic dilation (Radostits et al. 2007). In the present study, the amount of sand and stones found in the pre-stomachs and abomasum, although it may have contributed to the compaction, was not considered the primary cause.

In ruminants, the formation of phytobezoars has been related to the use of forages with high lignin content and low digestibility (Afonso \& Costa 2007) such as Stipagrostis foliata and Stipagrostis obtusa (Bath \& Bergh 1979), Opuntia sp. (Afonso et al. 2008), Stylosanthes sp. (Ubiali et al. 2013), and A. sisalana (Riet-Correa et al. 2011, Nascimento et al. 2016). The formation of phytobezoars in the present study was related to the palm fiber amount offered to the animals. Palm fiber is a highly fibrous material and difficult to digest (Rodrigues Filho et al. 2001). The increase in the amount of palm fiber in the diet may have exceeded the animals' ruminal digestion capacity. Phytobezoars formation in the omasum can cause obstruction, usually occurring in the duodenum and jejunum (Afonso \& Costa 2007), as observed in the present outbreak. The hematological changes observed in the present study, such as leukocytosis, increased plasma fibrinogen, and total plasma proteins, are similar to those described by Afonso et al. (2008). These changes characterize the inflammatory lesion resulting from gastrointestinal obstruction.

Palm oil cake has been used to feed ruminants as an alternative energy source for supplementing animals, mainly in feedlot systems. It has good nutritional characteristics for inclusion in the diet of ruminants, reducing costs, and replacing the use of concentrates based on corn and soybean meal (Silva et al. 2005, Abdalla et al. 2008, Cunha et al. 2012, Maciel et al. 2012). The palm oil cake has $14 \%$ to $18 \%$ crude protein in its composition, with high methionine content, in addition to high fiber content and energy value (Costa et al. 2011). On the other hand, palm fiber has a low digestibility coefficient, a lower protein content, and a high-fat content (Rodrigues Filho et al. 2001). In the present study, palm fiber was used to feed the animals due to its wide availability and low acquisition cost. However, the results demonstrate that there are limitations in its use in the feeding of cattle and that in large quantities, they can cause digestive disorders and even the death of animals.

In the inspection carried out in the refrigerator during the slaughter of animals of the affected batch, no fiber tangles were observed in the contents of the abomasum and prestomachs. These findings demonstrate that reducing the amount of palm fiber in the diet reduces digestive problems. The phytobezoars found in the omasum and abomasum of some animals had possibly been formed during the ingestion of fibers in large quantities.

Due to the wide availability of by-products from biodiesel production, mainly in Pará, studies are needed to establish the feasibility and safety limits for palm fiber in animal feed to avoid economic losses resulting from improper use in containment systems. 


\section{CONCLUSION}

The use of palm fiber at levels above $30 \%$ of the total diet in cattle feed can cause abomasum compaction, formation of phytobezoars and intestinal obstruction, causing significant economic losses. Therefore, for the use of palm fiber in the feeding of ruminants, complementary studies on adequate levels, composition, and nutritional value are necessary to avoid possible economic losses.

Conflict of interest statement.- The authors declare that there is no conflict of interest.

\section{REFERENCES}

Abdalla A.L., Silva Filho J.C.D., Godoi A.R.D., Carmo C.D.A. \& Eduardo J.L.D.P. 2008. Utilização de subprodutos da indústria de biodiesel na alimentação de ruminantes. Revta Bras. Zootec. 37(SPE):260-268. <https://dx.doi. org/10.1590/S1516-35982008001300030>

Afonso J.A.B. \& Costa N.A. 2007. Obstrução intestinal em bovinos, p.369-373. In: Riet-Correa F., Schild A.L., Lemos R.A.A. \& Borges J.R.J. (Eds), Doenças de Ruminantes e Equídeos. Vol.2. 3a ed. Gráfica e Editora Palloti, Santa Maria, RS.

Afonso J.A.B., Pereira A.L.L., Vieira A.C.S., Mendonça C.L., Costa N.A. \& Souza M.I. 2008. Alterações clínicas e laboratoriais na obstrução gastrintestinal por fitobezoários em bovinos. Revta Bras. Saúde Prod. Anim. 9(1):91-102.

Ashcroft R.A. 1983. Abomasal impaction of cattle in Saskatchewan. Can. Vet. J. 24(12):375-380. <PMid:17422338>

Bath G.F. \& Bergh T. 1979. A specific form of abomasal phytobezoar in goats and sheep. J. S. Afr. Vet. Assoc. 50(2):69-72. <PMid:551195>

Borges J.R.J., Cunha P.H.J., Moscardini A.R.C., Tortelly R., Franco G.L. \& Silva L.A.F. 2007. Compactação de abomaso em bovinos leiteiros: descrição de cinco casos. Ciênc. Anim. Bras. 8(4):859-864.

Câmara A.C.L., Afonso J.A.B., Costa N.A., Mendonça C.L. \& Souza M.I. 2009. Compactação primária do abomaso em 14 bovinos no Estado de Pernambuco. Pesq. Vet. Bras. 29(5):387-394. <https://dx.doi.org/10.1590/S0100736X2009000500005>

Cebra C.K., Cebra M.L. \& Garry F.B. 1996. Gravel obstruction in the abomasum or duodenum of two cows. J. Am. Vet. Med. Assoc. 209(7):1294-1296. <PMid:8837655>

Costa D.A., Colodo J.C.N., Ferreira G.D.G., Araújo C.V. \& Moreira G.R. 2011. Uso da torta de dendê na alimentação de ruminantes. Arq. Ciênc. Vet. Zool. UNIPAR, Umuarama, 14(2):133-137.

Cunha O.F.R., Neiva J.N.M., Maciel R.P., Miotto F.R.C., Neiva A.C.G. \& Restle J. 2012. Avaliação bioeconômica do uso da torta de dendê na alimentação de vacas leiteiras. Ciênc. Anim. Bras. 13(3):315-322. <https://dx.doi. org/10.5216/cab.v13i3.18464>

Erickson N. \& Hendrick S. 2011. Sand impactions in a Saskatchewan beef cow-calf herd. Can. Vet. J. 52(1):74-76. <PMid:21461212>

Furlan Júnior J. 2006. Dendê: manejo e uso dos subprodutos e dos resíduos. Embrapa Amazônia Oriental, Belém, PA. 37p.

Helayel M.A., Ramos A.T., Cordova F.M., Silva M.A.G., Sabino A.J., Barbosa F.B., Moron S.E. \& Burns L.V. 2012. Compactação ruminoabomasal decorrente da ingestão de caule de bananeira (Musa sp.) em bovinos: relato de dois casos. Revta Bras. Ciênc. Vet. 19(3):127-132. <https://dx.doi.org/10.4322/ rbcv.2014.094>

IBGE 2019. Produção Agrícola Municipal 2018. Instituto Brasileiro de Geografia e Estatística, Rio de Janeiro. Available at <https://cidades.ibge.gov.br/ brasil/pa/pesquisa/15/11863?indicador=11936> Accessed on June 2020.

Maciel R.P., Neiva J.N.M., de Araujo V.L., Cunha O.F.R., Paiva J., Restle J., Mendes C.Q. \& Lôbo R.N.B. 2012. Consumo, digestibilidade e desempenho de novilhas leiteiras alimentadas com dietas contendo torta de dendê. Revta Bras. Zootec. 41(3):698-706. <https://dx.doi.org/10.1590/S151635982012000300033>

Melendez P., Krueger T., Benzaquen M. \& Risco C. 2007. An outbreak of sand impaction in postpartum dairy cows. Can. Vet. J. 48(10):1067-1070. $<$ PMid:17987969>

Mesquita L.P., Abreu C.C., Nogueira C.I., Pavarini S.P., Seixas J.N., Varaschin M.S., Bezerra Júnior P.S. \& Wouters F. 2012. Surto de compactação primária de abomaso em bovinos leiteiros associado ao consumo de silagem de girassol. Pesq. Vet. Bras. 32(6):510-514. <https://dx.doi.org/10.1590/ S0100-736X2012000600007>

Moscardini A.R.C. \& Borges J.R.J. 2007. Compactação de abomaso, p.352-355 In: Riet-Correa F., Schild A.L., Lemos R.A.A. \& Borges J.R.J. (Eds), Doenças de Ruminantes e Equídeos. Vol.2. 3aㅗ ed. Gráfica e Editora Palloti, Santa Maria, RS

Nascimento E.M., Medeiros R.M., Simões S.V. \& Riet-Correa F. 2016. Compactação ruminal e obstrução intestinal em bovinos, associadas ao consumo de Agave sisalana Perrine (Agavaceae). Pesq. Vet. Bras. 36(8):719-723. <https:// dx.doi.org/10.1590/S0100-736X2016000800007>

Radostits O.M., Gay C.C., Hinchcliff K.W. \& Constable P.D. 2007. Veterinary Medicine: a textbook of the diseases of cattle, horses, sheep, pigs and goats. 10th ed. W.B. Saunders, Edinburgh. 2156p.

Riet-Correa B., Riet-Correa G. \& Riet-Correa F. 2011. Plantas que causam alterações mecânicas ou traumáticas em ruminantes e equinos, com ênfase em Stipa spp. (Gramineae). Pesq. Vet. Bras. 31(6):516-520.<https://dx.doi. org/10.1590/S0100-736X2011000600010>

Rodrigues Filho J.A., Camarão A.P. \& Azevedo G.D. 2001. Utilização da torta de amêndoa de dendê na alimentação de ruminantes. Embrapa Amazônia Oriental, Belém, PA. 24p.

Silva H.D.O., Pires A.J.V., Silva F.F., Veloso C.M., Carvalho G.G.P., Cezário A.S. \& Santos C.C. 2005. Digestibilidade aparente de dietas contendo farelo de cacau ou torta de dendê em cabras lactantes. Pesq. Agropec. Bras., Brasília, 40(4):405-411.<https://dx.doi.org/10.1590/S0100-204X2005000400013>

Ubiali D.G., Silva R.G.F., Oliveira L.P., Moraes L.G., Caldeira F.H.B., Pescador C.A., Souza M.A. \& Colodel E.M. 2013. Obstrução intestinal em bovinos associada ao consumo de Stylosanthes sp. (Fabaceae, Papilionoideae). Pesq. Vet. Bras. 33(2):148-154. <https://dx.doi.org/10.1590/S0100736X2013000200003>

USDA 2019. Oilseeds: world markets and trade. United States Department of Agriculture. Available at <https://downloads.usda.library.cornell. edu/usda-esmis/files/tx31qh68h/t435gp582/zs25xk513/oilseeds.pdf> Accessed on June 2019.

USDA 2020. World Agricultural Production. United States Department of Agriculture. Available at <https://apps.fas.usda.gov/psdonline/circulars/ production.pdf> Accessed on June 2020. 